Supplement of Biogeosciences, 12, 5429-5454, 2015

http://www.biogeosciences.net/12/5429/2015/

doi:10.5194/bg-12-5429-2015-supplement

(C) Author(s) 2015. CC Attribution 3.0 License.

(c) (i)

Supplement of

\title{
Oxygen minimum zones in the tropical Pacific across CMIP5 models: mean state differences and climate change trends
}

\author{
A. Cabré et al. \\ Correspondence to: A. Cabré (cabre@ sas.upenn.edu)
}

The copyright of individual parts of the supplement might differ from the CC-BY 3.0 licence. 

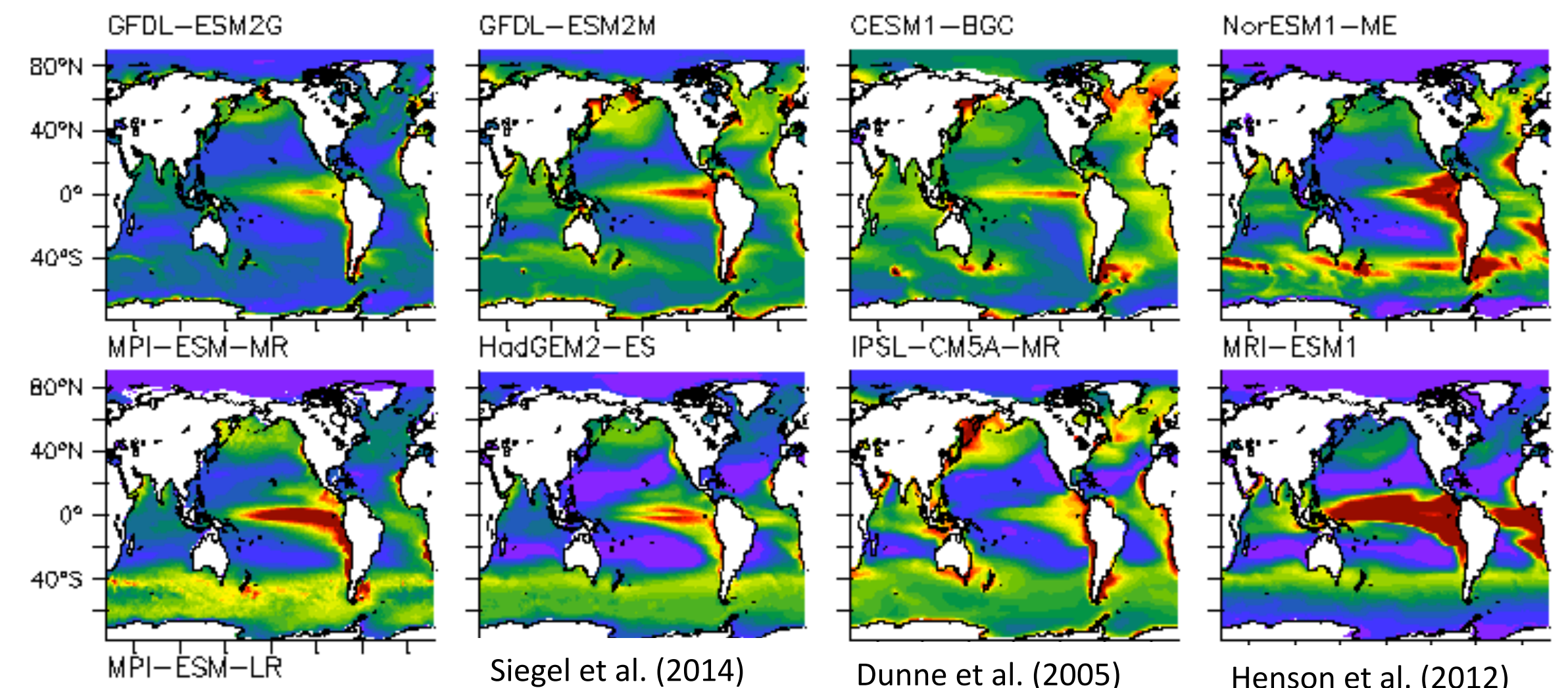

Siegel et al. (2014)
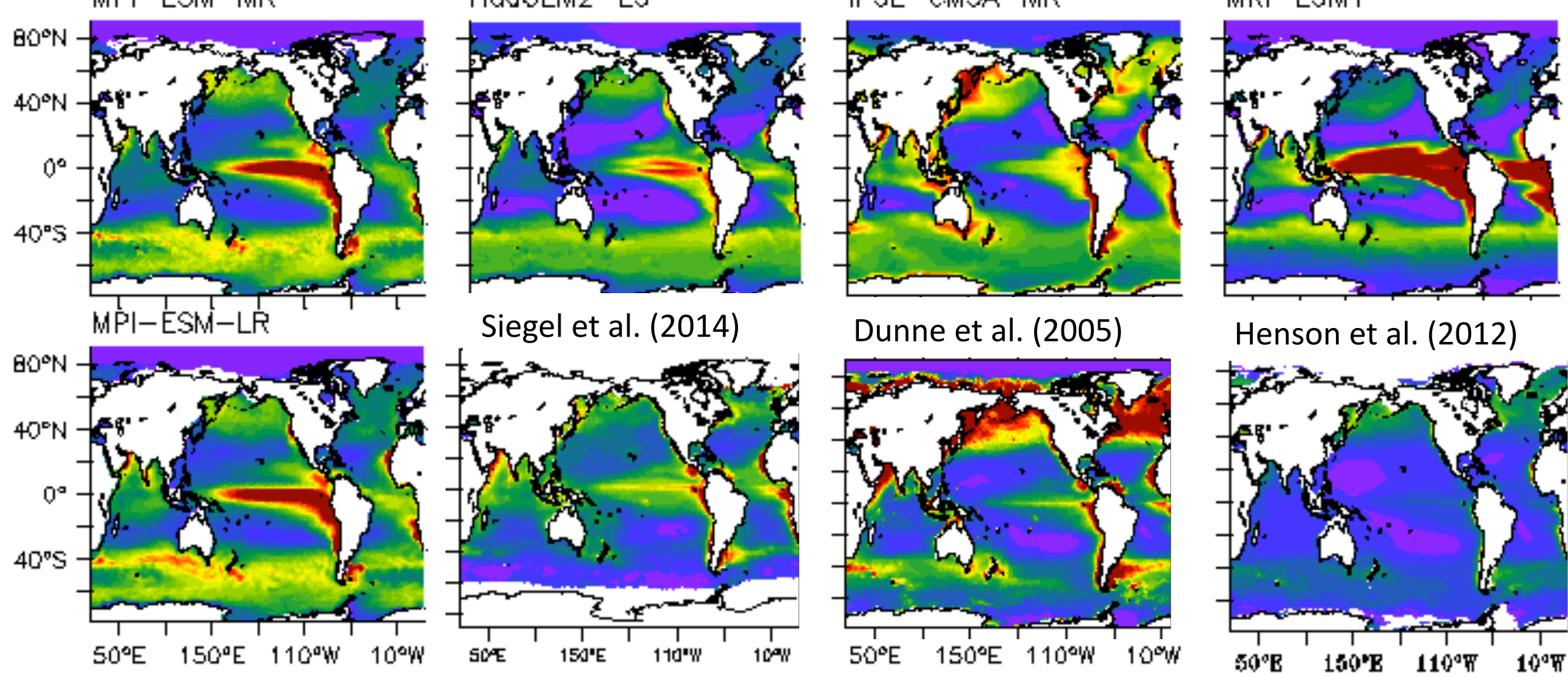

Henson et al. (2012)
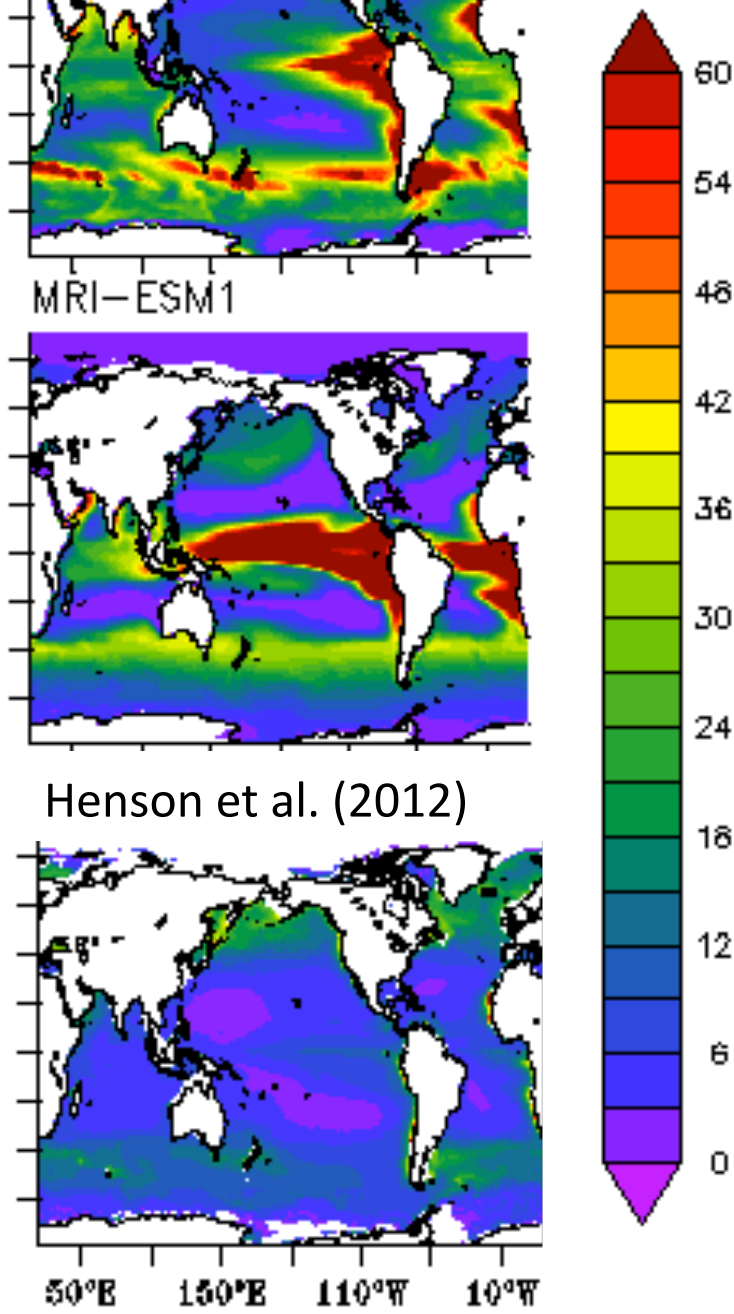

Figure S1: POC flux at $100 \mathrm{~m}\left[\mathrm{gC} / \mathrm{m}^{2} / \mathrm{yr}\right.$ ] across CMIP5 models. Last three panels show POC flux in the euphotic layer derived from satellite measurements in Siegel et al. (2014), Dunne et al. (2005) and Henson et al. (2012). 

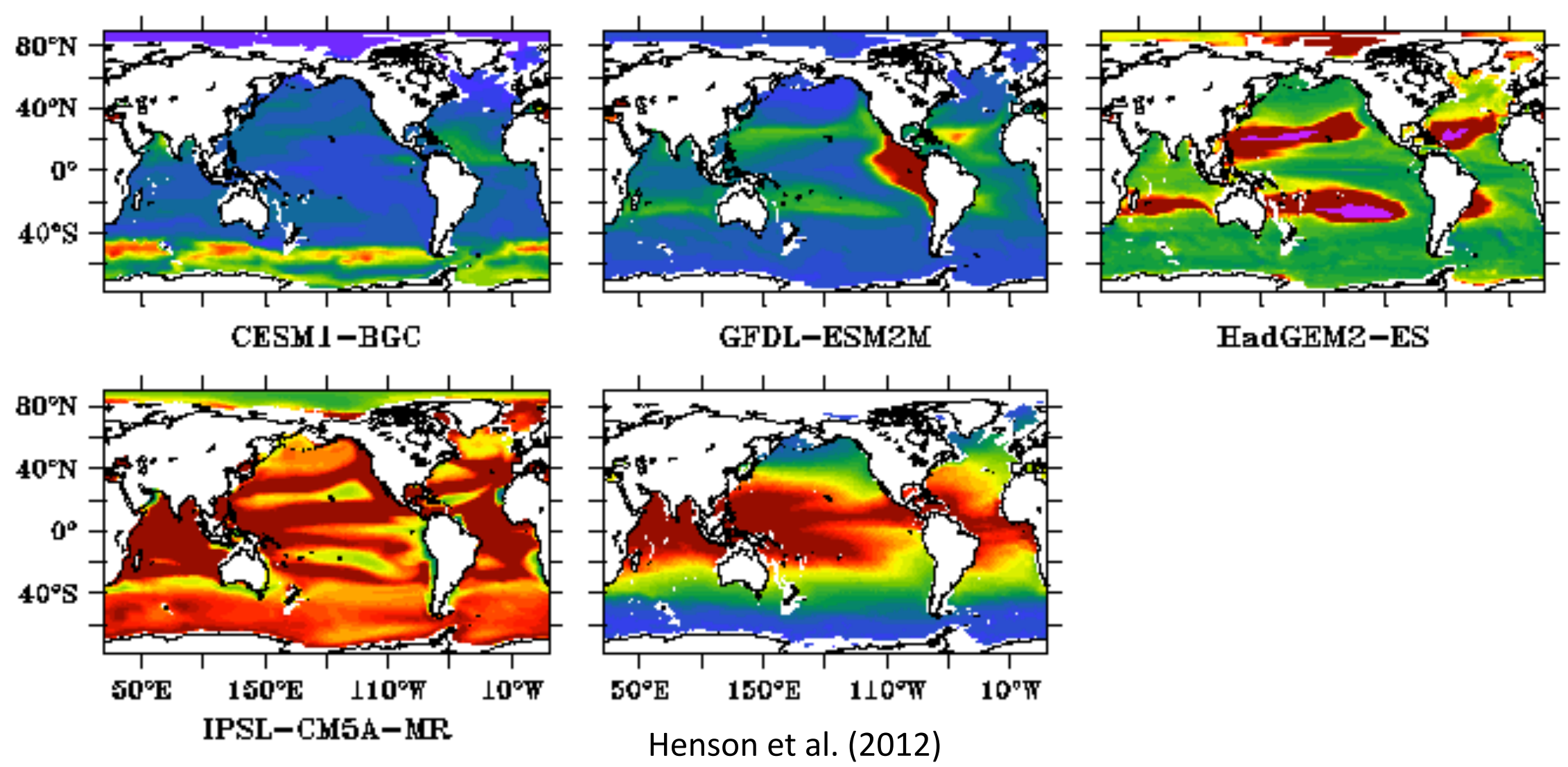

Figure S2: Transfer efficiency of POC flux from $100 \mathrm{~m}$ to $2000 \mathrm{~m}$ (POC flux at 2000m divided by POC flux at 100m) across the four CMIP5 models that provided a complete depth profile for POC. Last panel shows satellite-derived results from Henson et al. (2012). Note huge variation across CMIP5 models. 

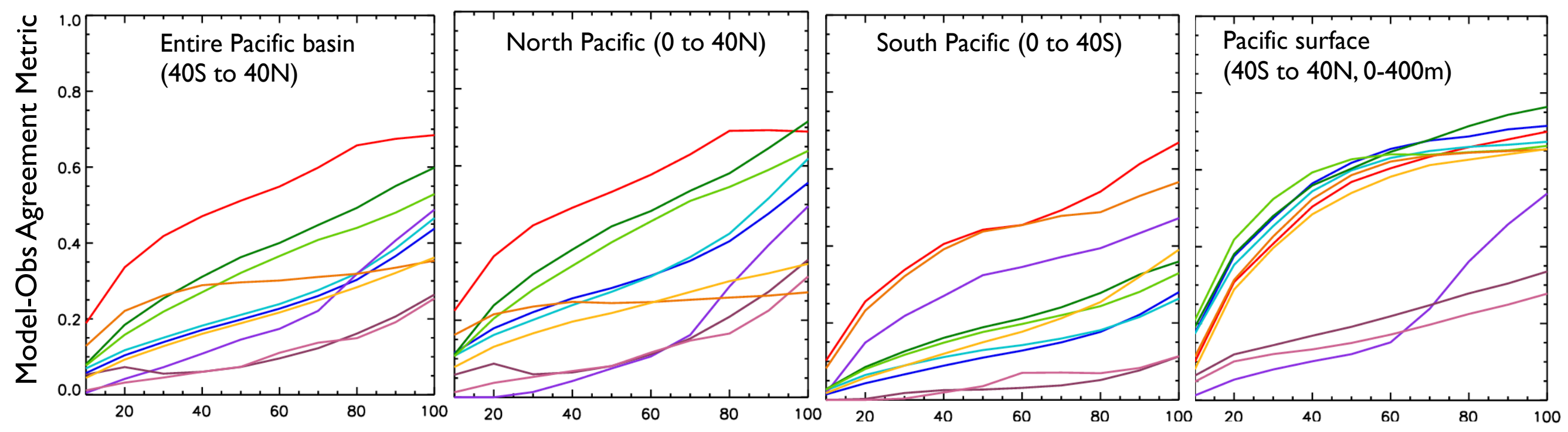

Threshold $\mathrm{O}_{2}$ for $\mathrm{OMZ}$ volume $\left(\mathrm{mmol} / \mathrm{m}^{3}\right)$

Figure S3: Model performance compared to observations in different regions and depths in the Pacific during the historical period (1960-1999). a)-d) Agreement between OMZ in models and observations described as the intersection of modeled and observed $\mathrm{OMZ}$ volumes divided by the union of modeled and observed $\mathrm{OMZ}$ volumes at different $\mathrm{O}_{2}$ thresholds ( $\mathrm{x}$ axis) and in different regions as labeled. Color bars as in Fig. 7. 

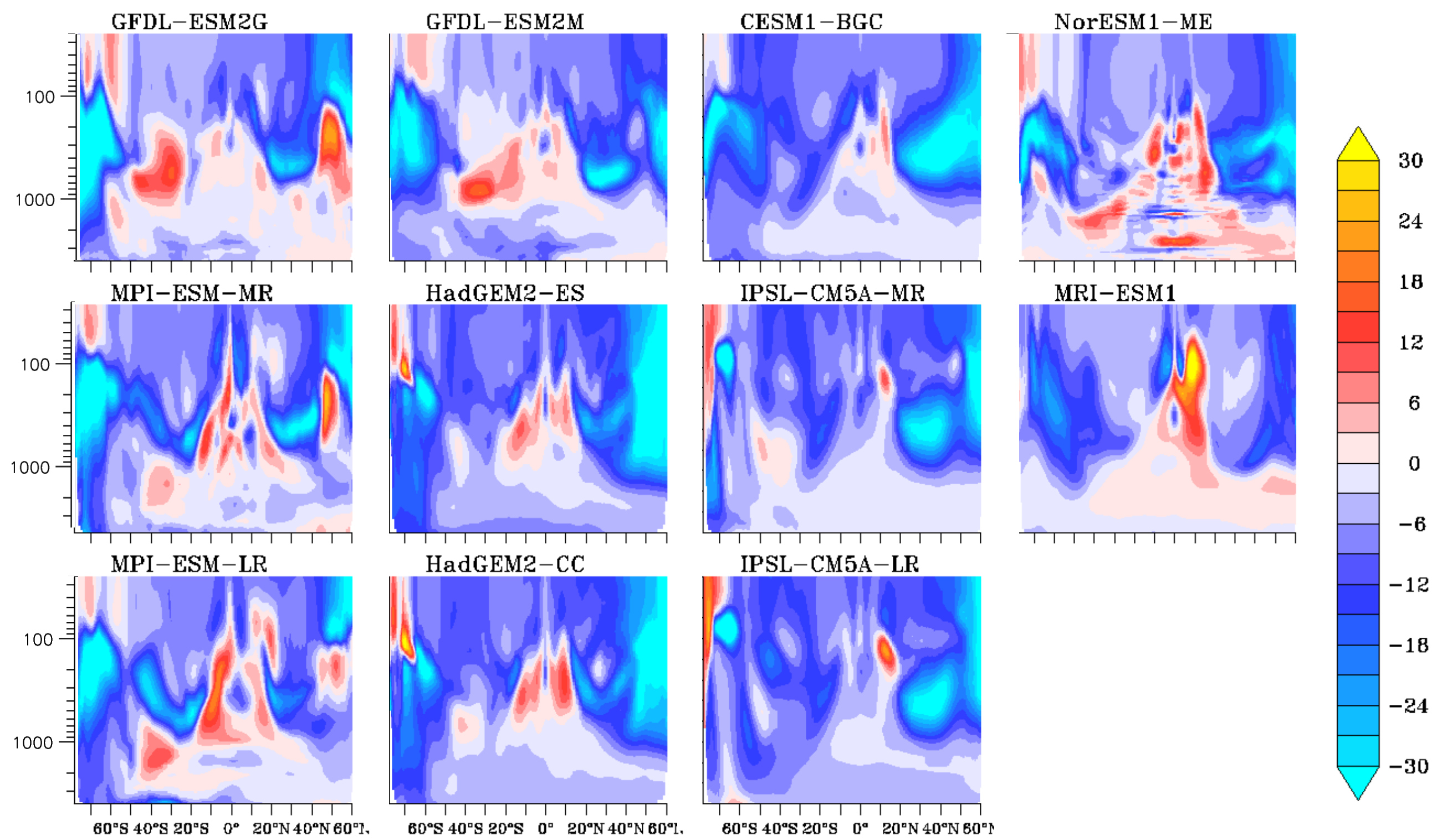

Figure S4: CMIP5 future projections for the period 2060-2099 with reference to the historical period (1960-1999) for oxygen concentration $\left(\mathrm{mmol} / \mathrm{m}^{3}\right)$ all averaged zonally between $180^{\circ} \mathrm{W}$ and $100^{\circ} \mathrm{W}$ in the Pacific Ocean (complementary to Fig. $8 \mathrm{c}$ ). 

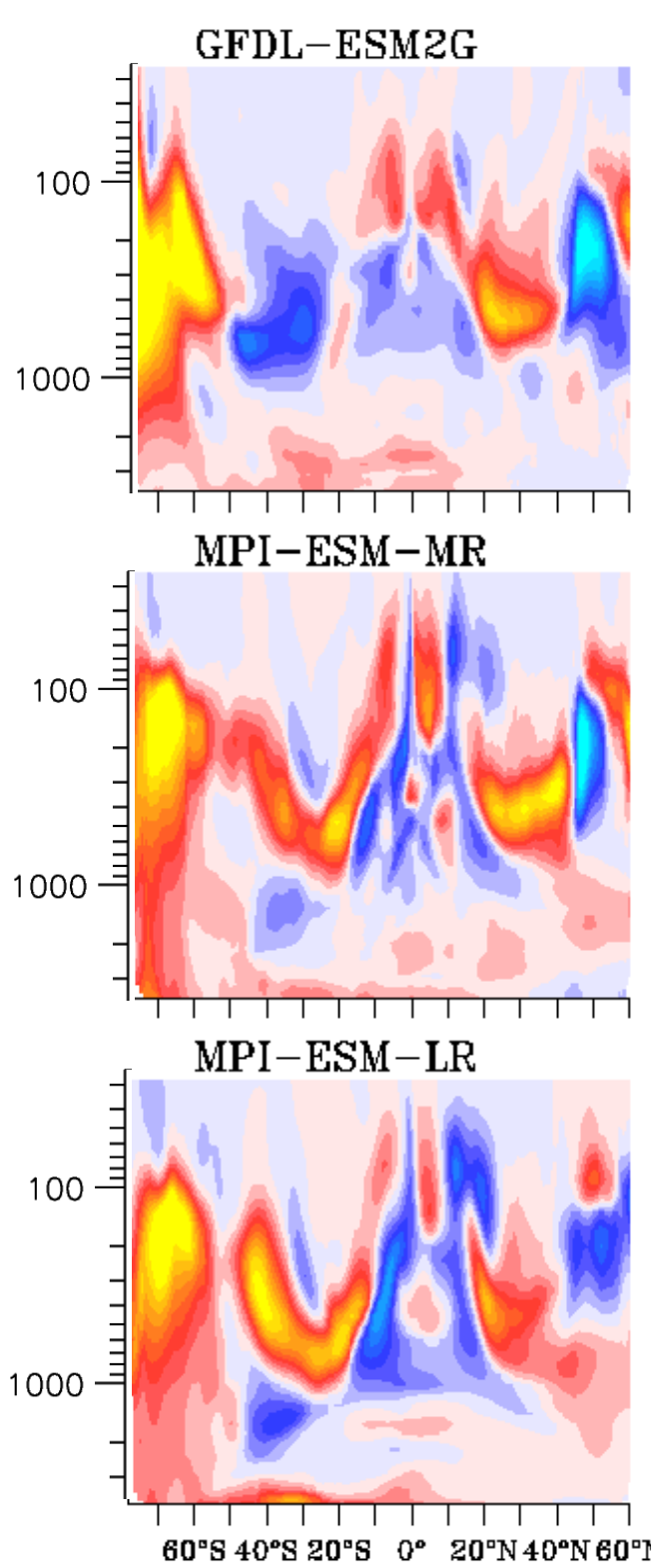
$\left(\mathrm{mmol} / \mathrm{m}^{3}\right)$ all averaged zonally between $180^{\circ} \mathrm{W}$ and $100^{\circ} \mathrm{W}$ in the Pacific Ocean (complementary to Fig. $8 \mathrm{f}$ ).
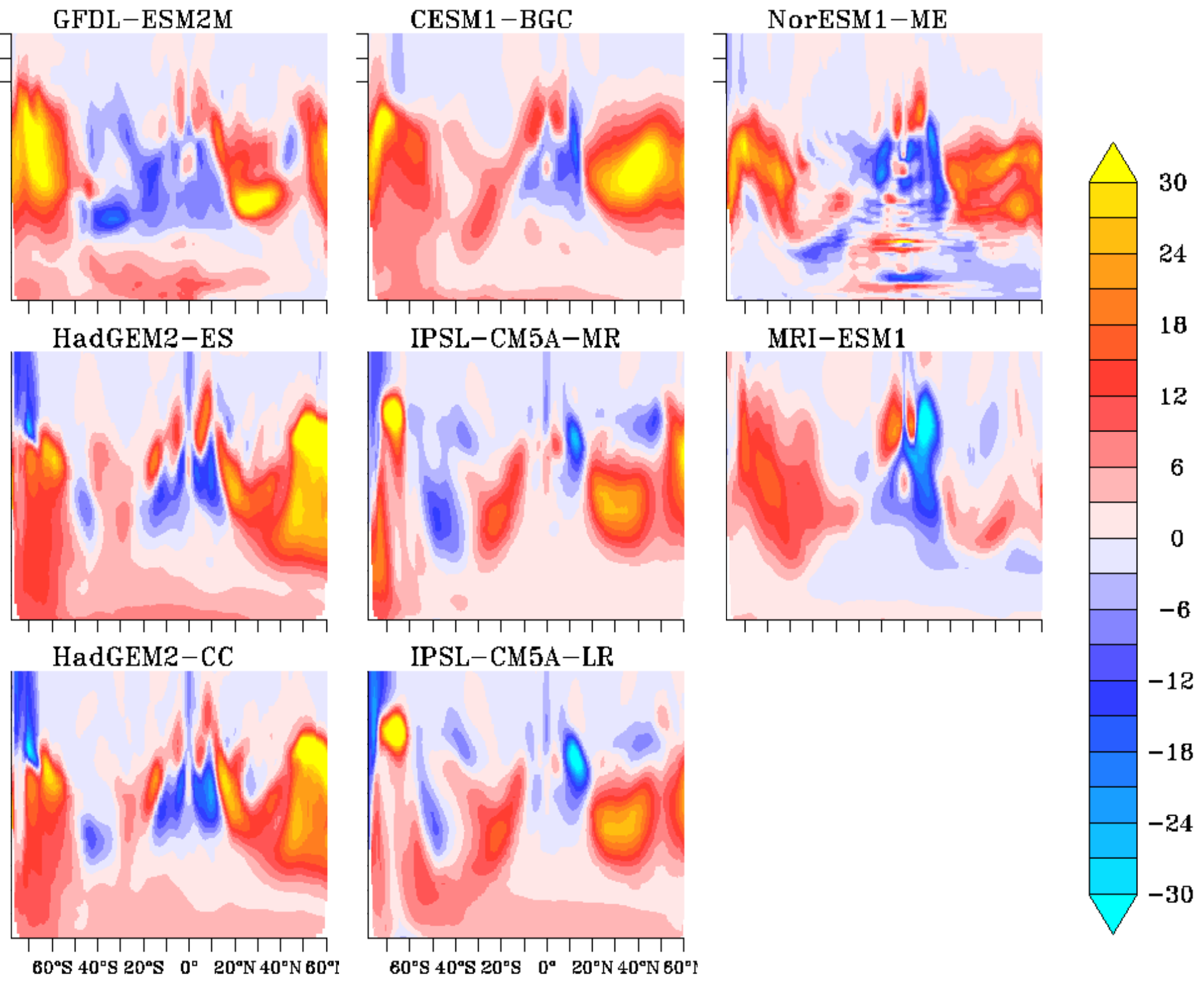

8

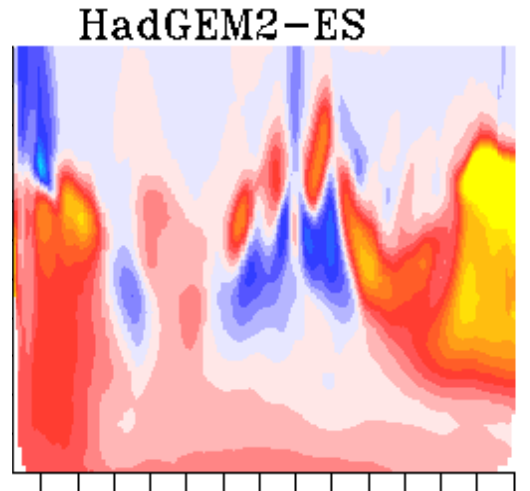

(1)

Figure S5: CMIP5 future projections for the period 2060-2099 with reference to the historical period (1960-1999) for AOU 

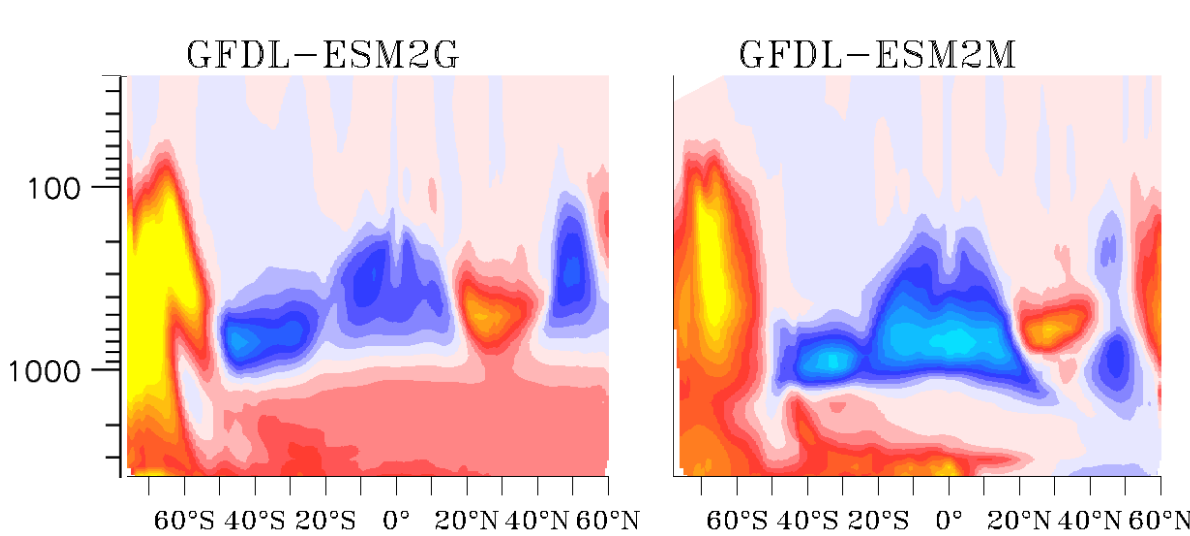

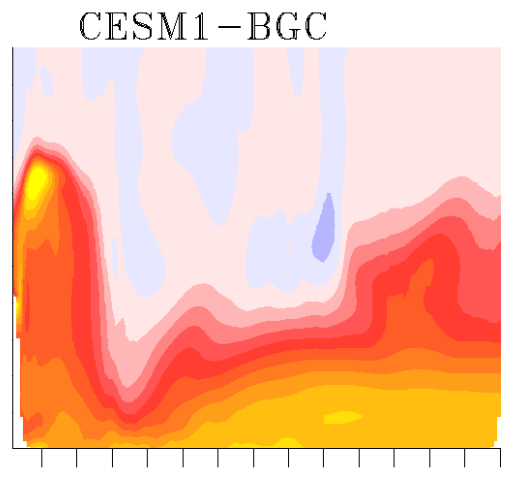

$60^{\circ} \mathrm{S} 40^{\circ} \mathrm{S} 20^{\circ} \mathrm{S} \quad 0^{\circ} \quad 20^{\circ} \mathrm{N} 40^{\circ} \mathrm{N} 60^{\circ} \mathrm{N}$
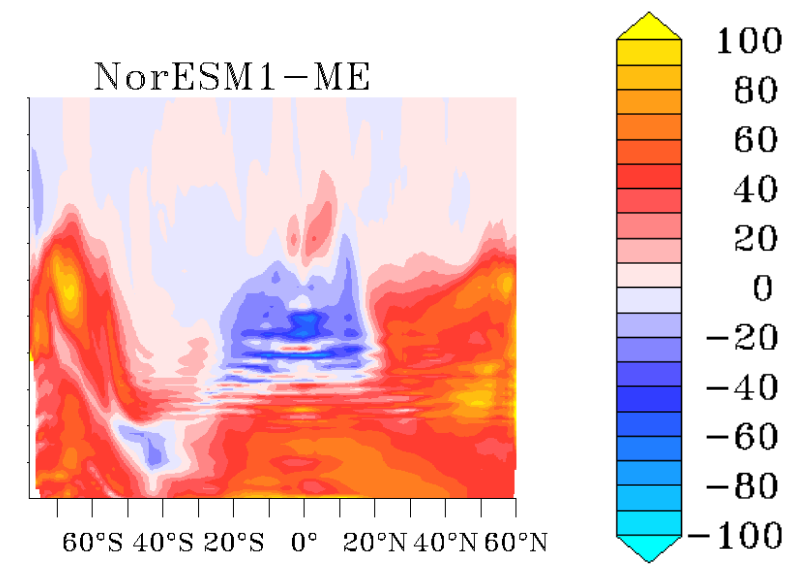

Figure S6: CMIP5 future projections for the period 2060-2099 with reference to the historical period (1960-1999) for watermass age [years] all averaged zonally between $180^{\circ} \mathrm{W}$ and $100^{\circ} \mathrm{W}$ in the Pacific Ocean (complementary to Fig. 8I). 
a) Temporal Correlation AOU and age

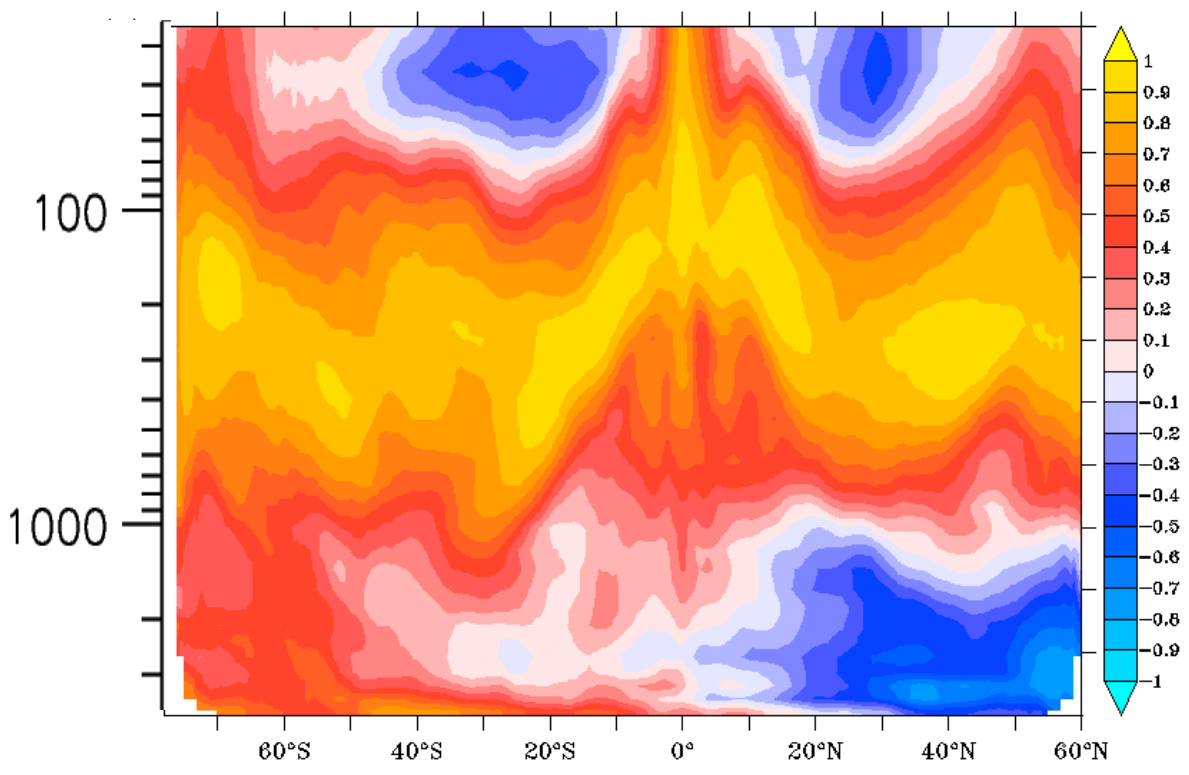

c) Temporal correlation O2sat and $\mathrm{O} 2$

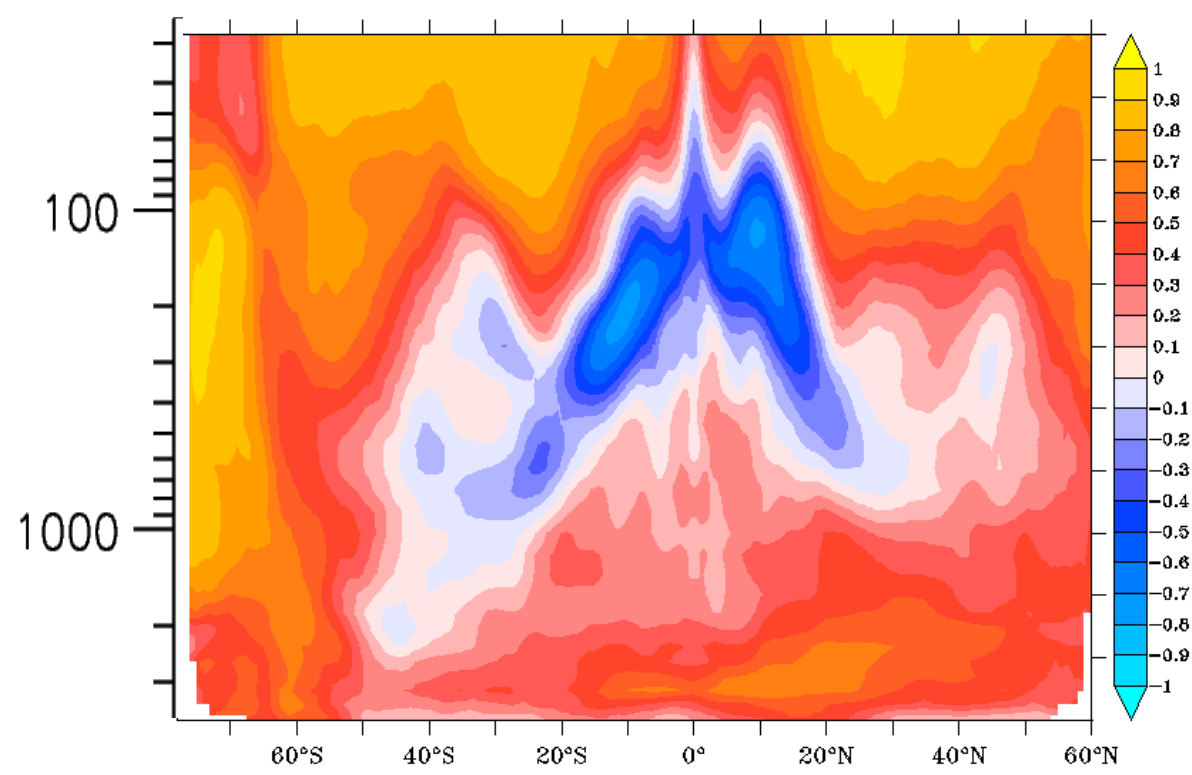

b) Temporal correlation $\mathrm{AOU}$ and $\mathrm{O} 2$

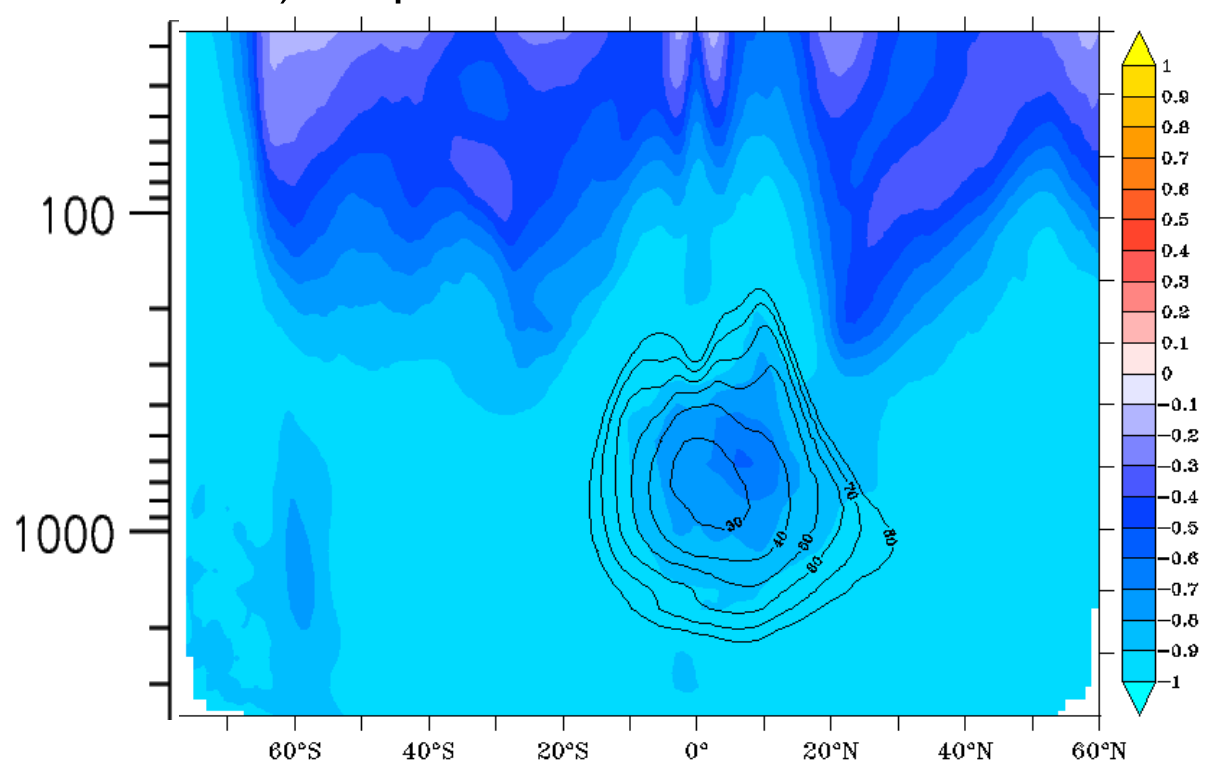

d) Temporal correlation AOU and O2sat

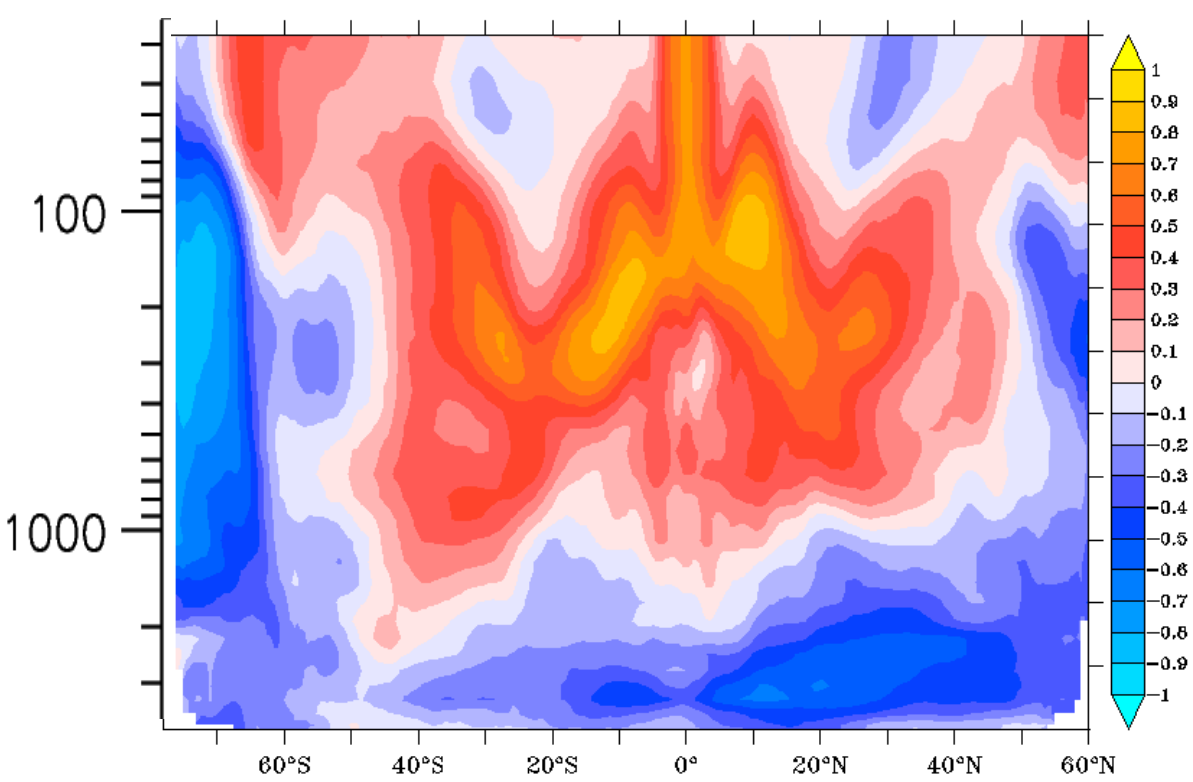

Figure S7: Interannual correlations calculated in a 100-year long control sample ("piControl" scenario). We show the multimodel average across all the available CMIP5 models. Oxygen contours are shown in Fig. S7b to show that low correlation at depth in the tropics is correlated with low oxygen zones. 


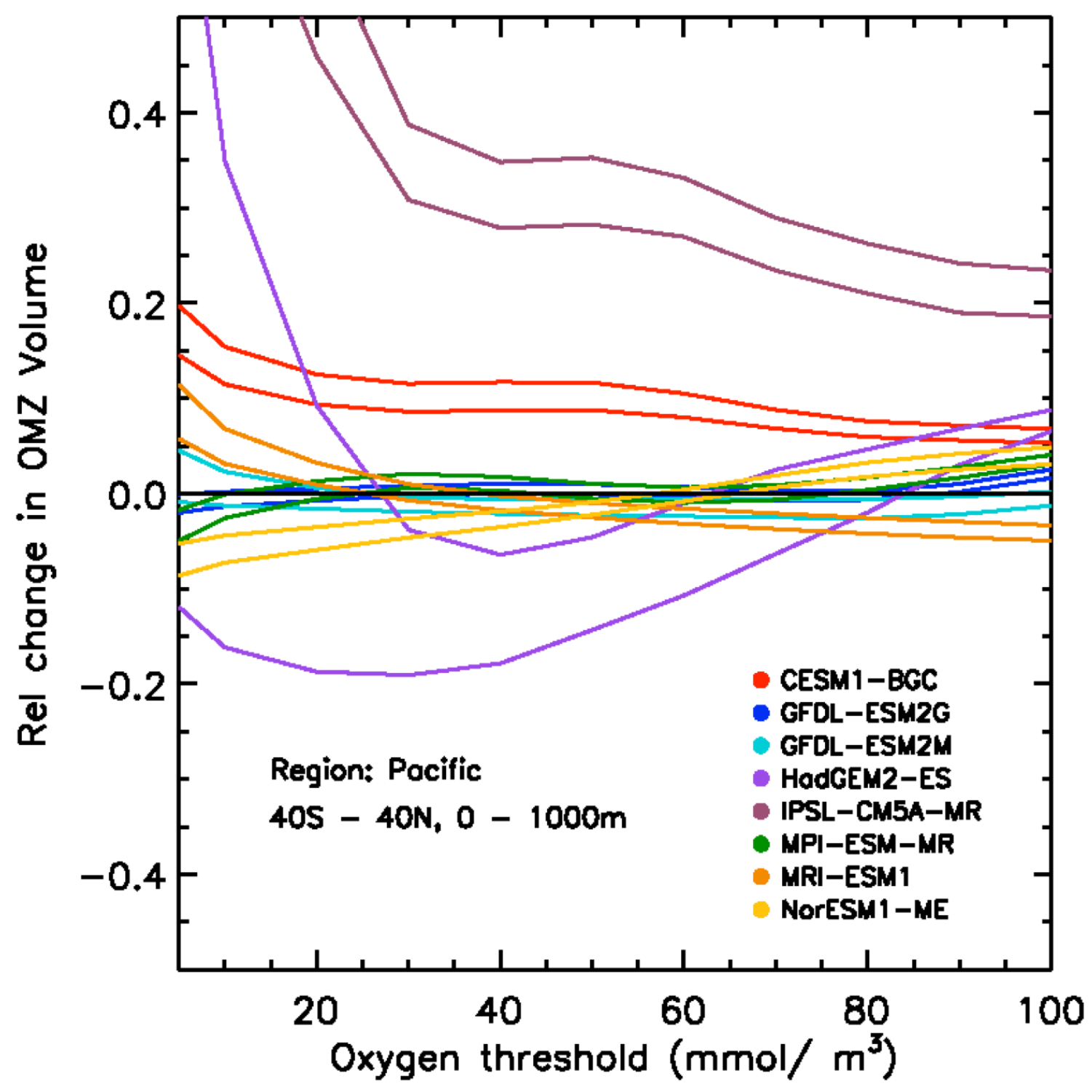

Figure S8: Figure complementary to Fig. 9 in the main text ( $y$ axis expanded). Relative change in the volume of oxygen minimum zones in the Pacific between $40^{\circ} \mathrm{S}$ and $40^{\circ} \mathrm{N}$ latitude to $1000 \mathrm{~m}$ depth over 100 years (from the period 1960-1999 to the period 2060-2099) projected by individual CMIP5 models. Each model projection is shown as a band that encompasses the natural variability (mean 100-year change \pm 1 standard deviation over 40 years in the control sample). MPI-ESM-LR, IPSL-CM5A-LR, and HadGEM2-CC are not shown for clarity, as these are very similar to MPI-ESM-MR, IPSLCM5A-MR, and HadGEM2-ES. 

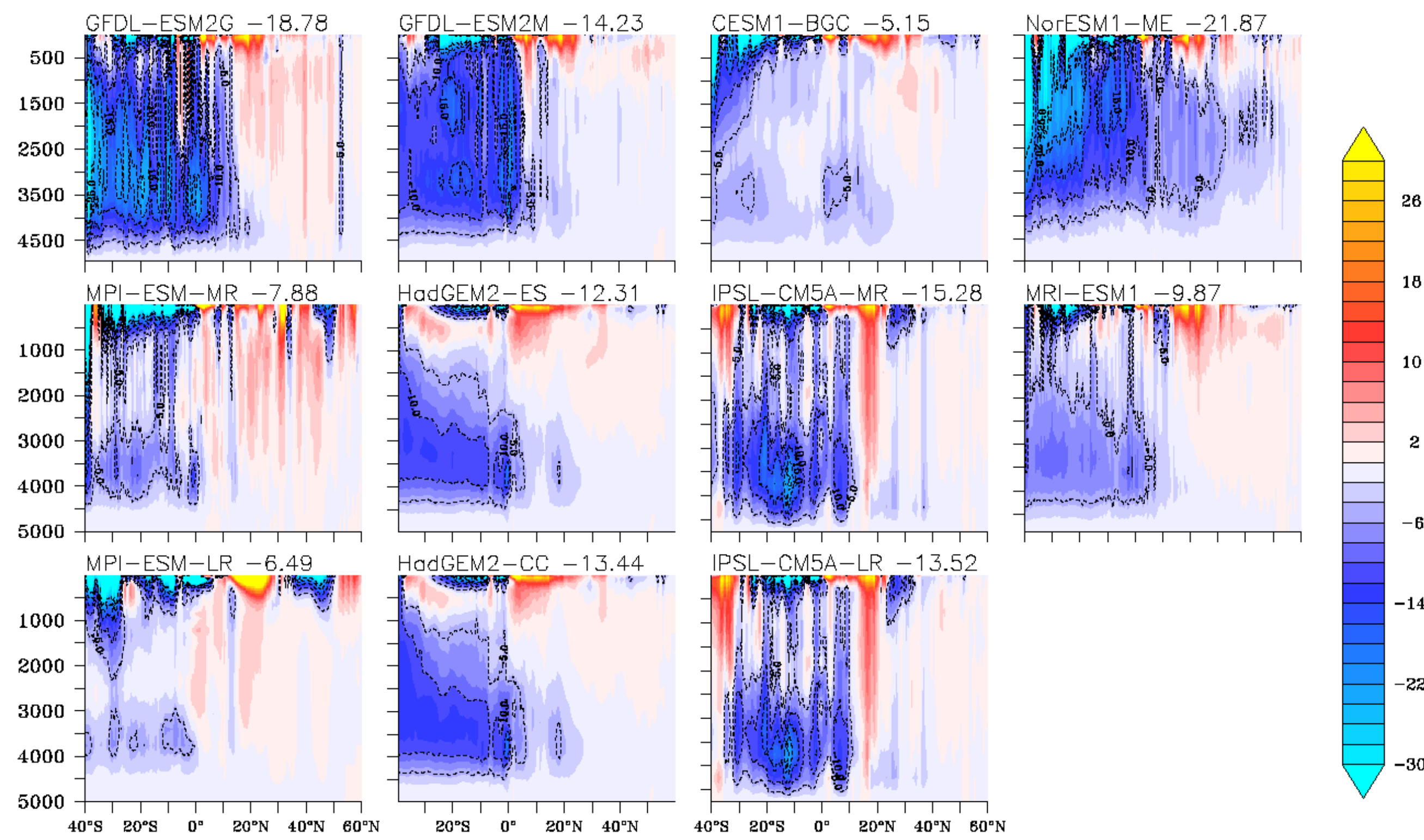

Figure S9: Meridional streamfunction in the Indo-Pacific Ocean across CMIP5 models (in Sv). The maximum strength of the AABW cell (deeper than $2000 \mathrm{~m}$ ) at 30 os is labeled next to the model name. 